\section{OBJEKTIVITAS IMAJINASI DALAM SENI}

\section{Susapto Murdowo}

\section{FBS Universitas Negeri Yogyakarta}

\section{Abstract}

In reality, art structure is dual and relational. A work of art can be viewed as a subjective and objective 'structure'. Arts always appear as continuous acts in imagination. The artists exist in the material world (the works of art) and in other life experiences. Besides, the objective understanding of imagination in art is expected to enhance epistemological ways of thinking and understanding as a reaction against a tendency towards verbalism of reality and truth. Finally, it is expected to motivate someone to be wiser, highly conscious with his willingness to create art works, as well as to build a system or framework in the forms of unique and personal expression.

Keywords: art structure, objectivity, imagination

\section{A. Pendahuluan}

Bersamaan dengan perkembangan cara pandang kontemporer yang lebih komprehensif terhadap rasionalitas dan kebenaran, sekarang terjadi pemaknaan kembali pengertian objektivitas. Pada pengertian lazim, istilah objek berasal dar kata bahasa Latin objectus, dan objectus ini dari objicere, obicere, yang berarti melempar ke muka, menempatkan berhadapan, dan membantah. Apabila diakarkan dari unsur-unsurnya maka terdapat $o b$ (terhadap) dan jacere (melempar) (Reese,1980,398-399). Pernyataan diatas memberi pengertian bahwa objek adalah apa saja yang tersaji bagi indra, pemikiran, maupun kesadaran kita sebagai subjek. Oleh karena itu, kalau kita mengatakan sesuatu sebagai objek, itu berarti kita menempatkannya "di depan" kita sebagai "bahan" bagi pemikiran, indra, dan kesadaran kita. Maka istilah objektivitas sebagai kata sifat itu berarti kondisi sesuatu sebagai objek.

Implikasi lebih jauh dari pemahaman tersebut mengarah pada dua kemungkinan. Pertama, kondisi objektif atau objektivitas itu akan tercapai kalau kita berhasil menempatkan dan memandang sesuatu sebagai objek. Kedua, objektivitas dalam pengertian tersebut selalu mengandaikan adanya subjek yang mengatasi objek karena memiliki indra, kesadaran, dan pemikiran (Van Gerwen, 1986,57). Dalam pengertian kedua ini, keberadaan subjek selalu merupakan alasan kenapa kita mengatakan ada objek di dunia ini. Namun pembedaan dan pengelompokan semacam ini dari sudut pandang pragmatisme sering kali justru menambah masalah daripada memecahkannya.

Hal itu tergambar dalam peran ilmu-ilmu dan teori-teori pengetahuan itu

Imaji, Vol.4, No.1, Februari $2006: 114$ - 120 sendiri, sebenarnya bertujuan untuk menjelaskan - atau dalam bahasa Descartes, mengklarifikasi, memperjelas- realitas, tetapi justru menjadi semakin ambigu dari dirinya sendiri. Satu pihak pembedaan itu dilakukan demi penjernihan pemahaman, tetapi di lain pihak upaya penjernihan tersebut justru memunculkan hal-hal lain yang harus: dijelaskan lagi. Sebuah ilmu yang tidak pasti (dalam hal pemahaman tentang objeknya) tentu sulit untuk dapat disebut ilmu. Oleh karena itu, sebuah ilmu yang tidak objektif atau tidak memegang objektivitas sebagai tolok ukurnya, mungkin tidak dapat diakui sebagai ilmu.

Kalau kita kembali pada apa yang sudah diandaikan di atas, kesulitan ini terjadi karena ilmu-ilmu selalu memuat suatu konvensi, suatu kesepakatan tertentu -ini dalam banyak hal- berarti kesepakatan bahasa- untuk memperjelaskan dan menghadirkan realitas. Apakah benar realitas itu semakin mengungkapkan diri, jika kita menganggapnya seolah berkesadaran? atau kita terpaksa mengakui bahwa upaya itu hanya untuk kita sendiri, untuk subjek-subjek ini ?. Ternyata pembedaan itu masih dianggap perlu kendati memuat paradoks yang harus diterima dengan arif. Kadang-kadang kita harus mengakui kekuatan permainan dalam hal ini. Seperti dikatakan Derrida, permainan itu selalu merupakan permainan ketidakhadiran dan kehadiran, keberadaan dan ketidakberadaan (Derrida,1978, 292). Perlu disadari selalu ada tegangan (tension) antara permainan dan kehadiran, sebagaimana dalam analogi kita juga ada tegangan ,antara subjektivitas dan objektivitas, akan tetapi dalam sebuah permainan, semua paradoks itu dapat berada dalam sebuah "harmoni" tersendiri yang masih mampu menjelaskan realitas. Berdasarkan penjelasan tersebut, maka bagaimana hendak dijelaskan soal "objektivitas imajinasi? Apakah mampu, atau apakah tepat, bila kita berbicara tentang objektivitas imajinasi? Sedangkan, di dalam terang teori korespondensi objektivitas sangat kuat dipertahankan, Apakah dapat diyakini bahwa daya imajinasi itu membawa kesesuaian (korespondensi) dengan objek atau realitas itu sendiri? Sekarang kita membahas bagaimana dapat terjadi pergeseran pengertian rasionalitas dan kebenaran dalam terang imajinasi. Dalam konteks tersebut objektivitas sebetulnya harus dikatakan pula sebagai tolok ukur yang saling mempengaruhi dan berdampingan dengan rasionalitas.

Objektivitas sebagai sifat kesesuaian dengan realitas atau objek, membuat kita menyadari kemasuk-akalannya, sehingga kita mengatakan sebagai kebenaran. Namun dari sini kita harus tetap ingat bahwa kebenaran itu bukan sekadar masalah korespondensi dengan realitas. Oleh karena itu, tidak adil untuk segera mengatakan bahwa kalau sesuatu itu objektif, kemudian sesuatu itu adalah kebenaran. Di atas telah dikatakan bahwa imajinasi itu mampu menghadirkan kondisi interaksional agar kebenaran yang lebih menyeluruh dapat terus diupayakan -bukan sekadar "dicapai”-

Objektivitas Imajinasi Dalam Seni (Susapto Murdowo) 


\section{B. Objektivitas Imajinasi}

Apakah mampu imajinasi menghadirkan objektivitas interaksional yang sungguh-sunguh, sehingga kebenaran yang interaksional pun dapa dimungkinkan?. Berdasarkan asumsi ini kita dapat mengandaikan bahwa objektivitas imajinasi itu selalu bersifat "di antara" (in between). Imajinasi mempunyai kemampuan menghadirkan berbagai imaji dan konsep (imajerial) dalam suatu harmoni tertentu kendati masing-masing masih dapat saling berlawanan, maka dalam pemahaman ini, "objektivitas" dapat diartikan secara baru -dengan menggunakan istilah teori korespondensi- bukan pertama-tama sebagai korespondensi dengan objek atau realitas, melainkan korespondensi antar objek, antar-realitas itu sendiri. Hal ini yang menjadikan kepenuhan makna kebenaran sebagai sesuatu yang interaksional dapat dipertanggungjawabkan, karena sesuatu yang objektif dan benar itu adalah sesuatu yang dialami di tengahtengah realitas, juga di tengah-tengah kehadiran objek-objek itu sendiri.

Imajinasi sendiri selalu membawa imaji. Apa yang dihasilkan pertama kali oleh imajinasi adalah imaji. Oleh sebab itu, imaji ini yang sesungguhnya memegang peranan penting dalam hal korespondensi interaksional antar objek Imaji adalah penentu sejauh mana kebenaran itu dapat dipertanggungjawabkan. Kebenaran, seperti kata Nietzsche, selalu merupakan asumsi yang menantikan penyelidikan. Secara analog dapat kita katakan, bahwa imaji yang menentukan kebenaran itu adalah imaji yang selalu menantikan objektifikasi secara interaksional. Maka kebenaran, objektivitasnya bersifat terbuka dan interaksional pula.

Kalau kebenaran harus selalu berkaitan dengan korespondensi dengan suatu realitas di luar imaji sendiri, maka dapat diduga kita tidak akan pernah mengalami apa yang dikatakan sebagai "puncak-puncak kebenaran" itu. Secara khusus Boulding pernah menegaskan kritik terhadap kriteria yang biasa kita terapkan pada kebenaran dan validitas (keabsahan). la mengaitkan peranan imaj sebagai pembentuk kebenaran; bahwa masalah kebenaran dan keabsahan tidak dapat dipecahkan secara tuntas, jika apa yang kita maksud dengan kebenaran suatu imaji adalah korespondensi dengan realitas tertentu di dunia yang di luar dirinya.

Kesulitan pada setiap teori korespondensi kebenarannya (sebagaimana sudah lama diketahui oleh para filsuf) adalah bahwa imaji hanya dapa dibandingkan dengan imaji. Imaji tidak pernah dapat dibandingkan dengan realitas luar mana pun. Di lain pihak, kesulitan pada teori koherensi kebenaran adalah bahwa koherensi atau konsistensi imaji tidak begitu saja merupakan apa yang kita maksud dengan kebenaran. Bahkan kebohongan dapat tampak. begitu koheren dan konsisten. Kita tidak mepunyai jaminan bahwa dunia liar yang menjadi terapan korespondensi imaji itu sendiri konsisten dan koheren. (Boulding,1968,165)

Imaji, Vol.4, No.1, Februari 2006 : 114 - 120
Imaji hanya dapat diperbandingkan dengan imaji, bukan dengan suatu realitas di luar dirinya sendiri, maka objek-objek di mana imaji itu terbentuk pun tidak perlu dipandang sebagai realitas di luar pengetahuan. Objek-objek yang dihadirkan dalam proses pengetahuan atau proses kreasi seni selalu merupakan objek-objek imajerial, yakni imaji-imaji itu sendiri, karena proses pengetahuan itu bukan suatu entitas yang dapat kita lihat di luar diri kita. Mengenai perihal kekuatan karakter imaji-imaji sebagai objek-objek imajerial yang sangat menentukan objektivitas imajinasi, maka kita dapat mengacu pada penjelasan berikut ini: ...bahwa Imaji seharusnya lebih mirip dengan objek daripada gambar mana pun. Sebab, bagaimanapun sangat mirip, orang telah berusaha membuat gambar yang mewakili sesuatu, selalu itu merupakan gambar dari sesuatu yang lain. Akan tetapi, secara mendasar bahwa imaji selalu merupakan imaji atas hal ini dan bukan atas hal yang lain. Kemudian pada akhirnya orang dapat memandang imaji sebagai sebuah kemiripan yang sangat (the superlikeness). (Wittgenstein, 1992, 119, no. 367,no.389).

Pengetahuan adalah suatu proses mental yang dapat dipertanggungjawabkan. Dalam pengertian ini, objektivitas adalah masalah mental, masalah korespondensi antar objek dan ini jelas berarti korespondensi antar imaji. Hal demikian itu, dapat disebut objektivitas imajinasi. Apakah pandangan seperti ini kemudian membawa kita kepada ketidakmampuan untuk mendekati realitas? Pertanyaan ini sama saja membawa kita kembali pada pemahaman bahwa realitas itu sesuatu yang "di luar" diri kita, jadi jawaban atas hal itu secara simplistis hanya akan mengabaikan pembicaraan kita selama ini.

Kita perlu tetap ingat bahwa kebenaran dan objektivitas itu senantiasa multi-disipliner, relasional dan interaksional. Kondisi interaksional ini hanya mungkin terjadi oleh imajinasi kita yang memunculkan imaji dan konsep imajerial semua itu secara mental. Dalam proses pengetahuan sebenarnya yang paling penting adalah mengkomunikasikan dan menginteraksikan imaji-imaji, karena imaji-imaji itu pada dasarnya dapat saling melengkapi satu sama lain. Dikatakan oleh Boulding: bahwa Kita dapat menelaah konsistensi, koherensi, nilai yang mempertahankan, stabilitas, dan kekuatan yang mengorganisasi di dalam sebuah imaji, sebab imaji mampu menyelidiki imaji. Kita tidak pernah dapat menyelidiki korespondensi imaji terhadap realitas, baik di wilayah nilai maupun di wilayah fakta. (Bouldng, 1968, 175-176)

Sejalan pernyataan tersebut, Boulding mengimplikasikan bahwa korespondensi antar-imaji sudah seharusnya dapat terjadi, sementara hal tersebut dalam penyelidikan kita mengarah kepada objektivitas imajinasi itu sendiri. Akan tetapi, pergeseran makna objektivitas ini tidak perlu dengan serta merta mengabaikan dan menegasi pengertian kita tentang objektivitas ilmiah selama ini.

Objektivitas Imajinasi Dalam Seni (Susapto Murdowo) 
Kita telah mengetahui bahwa peran imajinasi dalam ilmu-ilmu dan keberadaan ilmu-ilmu dipertahankan justru karena keberadaan imajinasi yang menyertainya. Objektivitas dalam arti keterpahaman objek, keterbuktian suatu hipotesis ilmiah, dan kemasukakalan berbagai hubungan (kausalitas) dalam ilmu-ilmu, sesungguhnya membutuhkan kehadiran imajinasi secara nyata. Objektivitas itu harus didukung oleh imajinasi. Para fisikawan berusaha menyajikan objektivitas atom atau bahkan dunia subatomik sambil mengatakan bahwa sebuah elektron itu sekaligus suatu partikel dan sebuah gelombang. Kalau begitu muncul pertanyaan, bagaimana hal itu dapat terjadi?. Elektron sekaligus partikel dan gelombang? Imajinasi kita mengatakan bahwa sebuah partikel tentu memiliki keluasan, entah dalam penggambaran sebagai butiran-butiran atau bentuk-bentuk lain. Akan tetapi bagaimana mungkin sesuatu yang bersifat spasial kemudian menjadi suatu gelombang ? Betapa pemahaman kita akan hal itu ternyata sangat tergantung kemampuan kita mengimajinasikannya. Sebuah gelombang bukan sekadar suatu kata tanpa arti dan tanpa acuan. Hospers membahasakan kegelisahan ilmiah itu secara lebih komunikatif sebagai berikut: Apakah molekul itu bulat, atau in hanyalah cara kita menggambarkannya, sebagaimana kalau kita memikirkan nukleus sebuah atom sebagai sesuatu yang mirip dengan pusat tata surya (matahari) dan elektron-elektron yang mengelilinginya seperti planet-planet? Anda bisa mengatakan, Itu hanyalah kutub positif dan kutub negatif dan dalam ha itu, apakah mempunyai bentuk?. Jika itu tidak berbentuk dan kita tidak dapa memahaminya tanpa bentuk, kemudian apa? apakah kita harus mengatakan bahwa molekul itu tidak tergambarkan? (John Hospers, 1990, 93)

Kita membutuhkan kekuatan imajinasi -hal ini seharusnya dapa dipertanggungjawabkan- untuk menggambarkannya. Apabila tidak demikian, apakah mungkin kita mendapat pengetahuan semacam itu, dan kita mengatakan sebagai pengetahuan?. Sebaliknya apakah objektivitas (ilmiah) semacam itu masih dapat kita sebut objektif ?. Pada titik ini, kita dapat mengatakan bahwa objektivitas itu tetap membutuhkan keberadaan imajinasi yang sering kita katakan subjektif itu. Pada titik ini pula kita dapat memahami apa yang telah dikatakan sebagai objektivitas imajinasi yang interaksional dan imajerial. Secara ekstrem dalam konteks ini bahkan dikatakan bahwa sesuatu itu objektif sejauh dapat diimajinasikan. Pada tahapan ini kita mendapatkan pemahaman yang selama in sering kita hindari, yakni keberadaan objektivitas itu di dalam subjektivitas sendiri. Seperti penjelasan berikut ini....bahwa segala hal itu memiliki suatu pernyataan dalam dirinya sendiri yang cukup terpisah dari interpretasi dan subjektivitas, adalah sebuah hipotesis yang tidak jalan, karena gagasan itu mengandaikan bahwa interpretasi dan subjektivitas itu tidak esensial, bahwa sebuah benda yang dibebaskan dari berbagai hubungan atau relasi masih tetap akan merupakan sebuah benda. Sebaliknya, sehubungan dengan karakter objektif yang jelas pada benda-benda, apakah hal itu hanya sekadar perbedaan tingkatan dalam diri subjek?, barangkali sesuatu itu perlahan berubah dan hadir pada kita sebagai suatu keberadaan (being) pada dirinya sendiri ((in-itself) — bahwa yang objektif itu hanya merupakan konsep keliru tentang sebuah genus dan sehuah antitesis di dalam diri yang subjektif?”.(Nietzsche, 1968, 560).

Akhirnya kita tiba pada titik yang cukup ekstrem, kita mencoba memperhatikan kritik Jean Baudrillard sehubungan dengan pesatnya teknologi komunikasi, berikutini.

"Tidak ada lagi sistem objek apapun. Dalam buku yang pertama $L e$ Systeme des objets, Gallimard, Paris, 1968, memuat kritikan tentang objek sehagai fakta nyata, substansi, realitas, dan nilai yang berguna. Objek itu dilihat sebagai tanda tetapi tanda yang penuh dengan makna... Penggambaran seluruh alam semesta yang sudah sangat dikenal ini, proyektif, imajiner, dan simbolik -masih sesuai dengan pandangan tentang status objek sebagai cermin subjek, dan itu mengarah pada kedalaman imajiner cermin dan pemandangan. Tetapi sekarang pemandangan dan cermin itu sudah tidak ada lagi: sebagai gantinya, muncullah layer (screen) dan jaringan (network). Bersamaan dengan kehadiran gambar televisi - televisi menjadi objek yang ultim dan sempurna untuk era baru ini -tubuh kita sendiri dan seluruh semesta yang melingkupinya menjadi sebuah layar control (monitor)."(Baudrillard, 1992: 151).

\section{Penutup}

Namun dalam perluasan pemahaman ini, kita tidak boleh dengan serta merta mengatakan bahwa segala produk buatan imajinasi adalah sesuatu yang objektif. Kita harus bijak mengacu pada kata-kata Nietzsche tentang kebenaran di depan, kita masih dapat mengatakan bahwa objektivitas imajinasi -objektivitas dalam pemahaman yang baru- adalah selalu objektivitas yang terbuka. Objektivitas imajinasi ini akan selalu diperlengkapi dan melengkapi dirinya.

Sementara ini, pemahaman yang lazim kita kenal mengenai karya seni dianggap produk intuisi, yang berarti tidak terukur dan tidak rasional atau tidak ilmiah. Akibat anggapan yang sangat meninggikan rasio ini, sehingga karya seni menjadi teripinggirkan. Pada kenyataannya, tanggapan (penghayatan) terhadap karya seni merupakan aktivitas emosional, artinya selalu bergerak dari imaji ke imaji yang lain dalam tindakan imajinasi. Namun demikian, karya seni merupakan produk suatu disiplin, artinya sebuah produk dari bidang pengetahuan yang tentu selalu diupayakan terus-menerus memiliki aturan-aturan atau metode tertentu. Oleh karena itu, karya seni pada dasarnya dapat dikaji menurut penggunaan aturan-aturan tersebut. 


\section{DAFTAR PUSTAKA}

Boulding, Kenneth E.(1969). The Image- Ann Arbor Paperback. Michigan: The University of Michigan,

Capra, Fritjof. (1977).The Tao of Physics- An Exploration of the Parallels Between Modern Physics and Eastern Mysticism. New York: Bantam Books,

Derrida, Jacques. (1978). Writing and Difference. London: Routledge and Kegan Paul Ltd.,

Kearney, Richard. (1994).The Wake of Imagination - Toward a Postmodern Culture. London: Routledge,

Nietzsche, Friedrich. (1968). The Will to Power. Terjemahan oleh Walter Kaufmann (ed.). New York: Vintage-Books: Adivision of Random House,

John Hospers, (1990 )An Introduction to Philosophical Artalysis, Third Edition, London: Routledge,

Jean Baudrillard, (1992),."'The Ecstasy of Communication", dalam Charles Jenks (ed.), The Yost-Modern Reader, London: Academy Editions,

Ricoeur, Paul (1978), The Rule of Metaphor, London \& Henly, Routledge\& Kegan paul

Reese, W.L. (1980)., Dictionary of Philosophy and Religion - Eastern and Western T73ougbt. New Jersey: Humanities Press,

Taylor, Mark C.dan Esa Saarinen. (1994.), Imagologies- Media Philosophy. London: Routledge,

VAN Gerwen, (1986),.Jef, S.J. "Root Metaphors of Society: Linking Sociologica and Moral-theological Analysis" dalam Louvain Studies. Vol. XI, No. 1,

Wittgenstein II , (1953).,Philosophical Investigation, 119, 630-632.

\section{BIODATA PENULIS}

I Made Bendi Yudha, adalah Dosen di Jurusan Seni Rupa FSRD Institut Seni Indonesia Denpsar. Menyelesaikan S-2 Program Studi Penciptaan Seni di Institut Seni Indonesia Yogyakarta. Aktif melakukan penelitian dan menulis karya ilmiah di bidang Perkembangan Seni Lukis di Indonesia. Di samping itu aktif pula dalam kegiatan pameran karya lukis di berbagai daerah di Indonesia dan luar negeri.

Titik Putraningsih, lahir di Yogyakarta 29 Agustus 1967. S-1 ISI Yogyakarta 1992. Menjadi staf pengajar pada Jurusan Sendratasik FBS sejak 1993 untuk mata kuliah Tari Gaya Yogyakarta. Karya ilmiah : (1) Workshop Seni Tari Sebagai Alternatif Motivasi Mahasiswa Untuk Meningkatkan Keterampilan Menari, (2) Resepsi Seniman dan Masyarakat pendukung Kesenian Badui Babussalam di Candran Sidoarum Godean Sleman (2004), (3) Upaya Meningkatkan Teknik Gerak Tari Puteri Gaya Yogyakarta (penelitian 2004), Peran Organisasi Tari Gaya Yogyakarta Dalam Kehidupan Tari Klasik Gaya Yogyakarta di Masa Kini. Karya Seni: Tari Puspita Sumawur (2001), Tari Rampak Kusuma Tamtama (2001), Tari Sekar Mangesti 2002

I Wayan Suardana, Lahir di Petulu Ubud Bali 1963. Menyelesaikan studi S-1 di ISI Yogyakarta Jurusan Kriya 1988. Diangkat menjadi staf pengajar di STSI (ISI) Denpasar 1991. Aktif mengikuti pameran seni rupa di berbagai daerah yaitu: Denpasar, Surabaya, Yogyakarta, Jakarta dan juga di Camberra Australia. Beberapa karya tulis yang pernah dihasilkan adalah: Proses Kreasi Seniman Ukir I Made Sutedja (1992), Penerapan Motif Timbal Pada Kerajinan Mebel di Silekarang Bali (1994), Penerapan Motif Hias Asing Pada Kerajinan Pigura (2003), Efektifitas Studi Lapangan Dalam Proses Belajar Mengajar (2004). Banyak juga membuat tulisan ilmiah pada jurnal Rupa, Artista, (PPPG Kesenian Yogyakarta), dan tulisan populer di majalah Wrerta Cita STSI Denpasar. Sekarang sedang menempuh pendidikan S-2 Penciptaan Seni Program Pascasarjana ISI Yogyakarta.

Muhammad Mukti, adalah dalang Wayang Sambung (wayang dakwah), tinggal di Yogyakarta. Tahun 1990 setelah lulus dari Akademi Seni Karawitan Indonesia (ASKI) Surakarta, kemudian menjadi dosen tetap Universitas Negeri (UNY) Yogyakarta. Tahun 2000 menempuh kuliah S 2 jurusan Seni Pertunjukan di Sekolah Tinggi Seni Indonesia (STSI) Surakarta, lulus tahun 2002 dan mendapatkan gelar M. Sn. Sekarang aktif dalam usaha perbaikan umat. 
Dahlan Taher, lahir di Makassar, 10 Oktober 1973. Lulus S-1 Jurusan Musik Institut Seni Indonesia Jogjakarta, Fakultas Seni Pertunjukan (1997) dan S-2 Jurusan Psikologi Univesitas Gadjah Mada, Fakultas Psikologi (2005). Karya tulis yang dihasilkan antara lain: (1) Tinjauan Melodi Pada Era Musik Klasik, Romantik, Dan Moderen di buletin Laras, (2) Keyboard Grade 1, pelajaran untuk bermain kibor, (3) Piano Anak 1, pelajaran bermain piano untuk anak prasekolah. Karya seni antara lain: (1) Sonatina untuk piano, (2) Once Upon A Time In Malioboro untuk tape, (3) Romance untuk biola dan piano, (4) Flamenco untuk solo piano dan adaptasi untuk duet gitar, (5) Andante Appasionata untuk piano dan trombone, (6) Instropeksi untuk kibor dan puik-puik.

Sumaryadi, lahir di Kulon Progo, 31 Mei 1954. Lulus Sarjana Muda dan Sarjana di IKIP YOGYAKARTA, dan S-2 di Pascasarjana IKIP Jakarta. Di samping kesibukannya selaku dosen pada Jurusan Pendidikan Sendratasik FBS UNY, Kepala Divisi Humas UNY, Redaktur Majalah Ilmiah Populer 'WUNY', Pemimpin Redaksi Jurnal Seni dan Pendidikan Seni 'IMAJI', Sekjen Pengurus Daerah Badan Pembina Seni Mahasiswa Indonesia Daerah Istimewa Yogyakarta, dan Ketua Umum Dewan Kesenian Kabupaten Sleman, masih sempat menulis: Tantangan Seniman Seni Wisata dalam Menghadapi Era Industri Pariwisata (UNY, 1999), Pendidikan Drama untuk Anak-anak (UNY, 2000), Catatan untuk Guru-guru Sastra di Sekolah (UNY, 2000), Nilai-nilai Pendidikan dalam Drama (ISI, 2001), lakon sandiwara Tumpes Kelor (FKY, 2002), dan When Local Values and Globalization Meet (Chiang Rai, Thailand, February 12-14, 2004).

I Wayan Suardana, lahir di Bali 31 Desember 1961. Menyelesaikan studi S-1 di ISI Yogyakarta tahun 1988 dan S-2 di ITB Bandung tahun 2001. Tercatat sebaga Staf Pengajar Jurusan Pendidikan Seni Rupa FBS UNY. Aktif melakukan penelitian dan menulis karya ilmiah di bidang Perkembangan Seni Lukis di Indonesia.

Djohan Salim, lahir Palembang 17 Desember 1961. Sekarang tercatat sebaga pengajar di Jurusan Musik FSP ISI Yogyakarta. Menyelesaikan S-1 Jurusan Musik ISI Yogyakarta dan S-2 Psikologi Perkembangan dari Program Pascasarjana UGM. Karya ilmiah yang dihasilkan antara lain: (1) Pengaruh Pendidikan Musik Jangka Pendek terhadap Kreativitas Anak, (2) Pengembangan Pendidikan Musik dalam Perspektif Kognisi: Kajian Psikologi Musik, (3) Psikologi Musik Yogyakarta : Penerbit Buku Baik, (4) Musik dan Pengaruh Sosial, (5) Asosiasi Sosiodemografik dan Pengaruh Sosial Terhadap Selera Musik, (6) Kepemimpinan Gamelan: Analisis Proses Pengambilan Keputusan pada Tingkat Individu,

Imaji, Vol.3, No.1, Februari 2005: 121 - 13
Kelompok dan Sistem, (7) Pengaruh Stimuli Elemen Tempo \& Timbre dalam Musik Gamelan Jawa terhadap Respon Emosi Musikal, dan (8) Aspek Psikologi Sosial Kelompok Musik”Campur Sari” di Yogyakarta.

Kusnadi, adalah Staf Pengajar di Jurusan Seni Tari FBS UNY. Menyelesaikan S-2 di Program Pascasarjana UNY tahun 2002. Aktif melakukan penelitian dan menulis karya ilmiah di bidang Perkembangan Seni Tari di Indonesia. Di samping itu aktif pula dalam kegiatan penciptaan dan pagelaran tari di berbagai daerah di Indonesia dan luar negeri.

Susapto Murdowo, lahir di Yogyakarta, 5 Mei 1956. Sl-nya diselesaikan di STSRI ASRI Yogyakarta tahun 1982 dan S-2-nya dirampungkan di IM Jurusan Seni Murni tahun 2000. Sejak 1987 menjadi dosen pada Jurusan Pendidikan Seni Rupa FBS UNY. Karya tulis: Tinjauan Kesenimanan, Proses Penciptan, Karya Lukisan Heri Dono, Aming Prayitno, dan Widayat (2000), Semiotika Rupa sebagai Pendekatan Analisis Karya Seni Rupa (2001). Karya seni: Nominasi karya seni rupa dalam rangka Phillip Morris Award tingkat Asia (1995, 1996, 1997), Nominasi Lomba Disain Batik Internasional di Yogyakarta (2002). 